\title{
Efforts to Improve Learning Results Theme 4 About Pantun Using Video Media
}

\author{
Sulastri \\ SD Negeri Kedungoleng 03 \\ nazhanayaka@gmail.com
}

\section{Article History}

accepted 14/11/2020

approved $21 / 11 / 2020$

published 26/11/2020

\begin{abstract}
The purpose of this study was to improve student learning outcomes in subject matter 4 about rhymes through video media. This research is a classroom action research (PTK) which is conducted in three cycles, each cycle consisting of planning, implementation, observation, and reflection stages. The subjects of this study were students of class V SD Negeri Kedungoleng 03 Paguyangan, Brebes Regency in the academic year 2020/2021, totalling 18 students. The technique of collecting data uses observation and tests of student learning outcomes, and notes on the results of reflection and evaluation. Data analysis includes quantitative analysis and qualitative analysis, data presentation, and drawing conclusions. The results of learning improvement show that the application of video media in learning theme 4 about a poem can improve student learning outcomes in class V SD Negeri Kedungoleng 03 Paguyangan, Brebes Regency in the academic year 2020/2021 as evidenced by the percentage of completeness of learning outcomes in pre-cycle, cycle I of $38 \%$ becomes $77 \%$ in cycle II.
\end{abstract}

Keywords: theme 4, a poem, videos

\begin{abstract}
Abstrak
Tujuan penelitian ini adalah meningkatkan hasil belajar siswa pada materi tema 4 tentang pantun melalui media video. Penelitian ini merupakan penelitian tindakan kelas (PTK) yang dilaksanakan dalam tiga siklus, setiap siklus terdiri dari tahap perencanaan, pelaksanaan, observasi, dan refleksi. Subjek penelitian ini adalah peserta didik kelas V SD Negeri Kedungoleng 03 Paguyangan Kabupaten Brebes tahun pelajaran 2020/2021 yang berjumlah 18 peserta didik. Teknik pengumpulan data menggunakan observasi dan tes hasil belajar siswa, dan catatan hasil refleksi dan evaluasi. Analisis data meliputi analisis kuantitatif dan analisis kualitatif, penyajian data, dan penarikan kesimpulan. Hasil perbaikan pembelajaran menunjukkan bahwa penerapan media video dalam pembelajaran tema 4 tentang pantun dapat meningkatkan hasil belajar siswa di kelas V SD Negeri Kedungoleng 03 Paguyangan Kabupaten Brebes tahun pelajaran 2020/ 2021 yang dibuktikan dengan persentase ketuntasan hasil belajar pada prasiklus, siklus I sebesar $38 \%$ menjadi $77 \%$ pada siklus II.
\end{abstract}

Kata kunci: tema 4, pantun, video

Social, Humanities, and Education Studies (SHEs): Conference Series https://jurnal.uns.ac.id/shes

p-ISSN 2620-9284

e-ISSN 2620-9292 


\section{PENDAHULUAN}

Proses belajar mengajar yang berkualitas ditentukan oleh guru sendiri. Guru merupakan salah satu faktor penentu dalam keberhasilan pembelajaran. Oleh karena itu, guru dituntut memiliki kemampuan yang baik untuk mengetahui adanya masalah yang berkaitan dengan praktik pembelajaran yang dikelolanya. Dengan mengetahui adanya masalah dalam pembelajaran, guru diharapkan dapat memperbaiki dan menemukan solusi yang sesuai untuk peserta didiknya. Guru merasa bahwa ada sesuatu yang tidak beres di kelasnya. Jika dibiarkan akan berdampak buruk bagi proses dan hasil belajar siswa. Setelah melihat prestasi belajar siswa, kemudian guru merefleksikan diri dan akhirnya mengidentifikasi masalah dalam proses belajar. Dalam proses pembelajaran tema 4 kelas $\mathrm{V}$, peneliti menemukan beberapa masalah yang menyangkut tingkat pemahaman siswa sangat rendah.

Kondisi awal siswa-siswa kelas V SD Negeri Kedungoleng 03 sebelum diadakan penelitian mereka sudah dapat melakukan aktivitas membaca, menyusun sebuah pantun akan tetapi mereka belum sepenuhnya memahami syarat- syarat yang harus dipenuhi dalam penyusunan pantun. Peserta didik belum baik dalam memilih kata dalam penyusunan sebuah pantun yang menarik. Hal ini terbukti berdasarkan nilai evaluasi mata pelajaran Bahasa Indonesia di tema 4 sebelum diadakan penelitian masih rendah dan belum memenuhi KKM yang telah ditetapkan.

Bukti menunjukan bahwa siswa kelas V SD negeri Kedungoleng 03 pada mata pelajaran Bahasa Indonesia materi pantun, hasil tes studi awal yang dilaksanakan pada tanggal 19 Oktober 2020 diperoleh data dari 18 siswa, baru 7 siswa atau 38\% yang mencapai ketuntasan belajar, sedangkan yang belum tuntas belajar sebanyak 11 siswa atau 62\% dan rata-rata kelas 69,33 dengan KKM 68.

Fenomena di atas menunjukkan pembelajaran belum berhasil secara optimal. Untuk itu, penulis mengidentifikasi sebab-sebab ketidakberhasilan penulis dalam pembelajaran yang diantaranya adalah sebelum diadakan penelitian, guru dalam proses pembelajaran di kelas menggunakan model pembelajaran yang masih konvensional yang banyak didominasi dengan ceramah, sehingga pembelajaran menimbulkan kesan yang kurang menarik bagi siswa dan membuat siswa kurang semangat dan minat dalam belajar di kelas rendah. Siswa masih banyak yang belum memperhatikan penjelasan guru serta siswa kurang termotivasi untuk ikut andil dalam pembelajaran yang ditunjukkan dengan peran guru yang lebih dominan di pembelajaran. Berdasarkan hasil pengamatan tersebut dapat disimpulkan bahwa rendahnya nilai hasil belajar siswa di SD Negeri Kedungoleng 03 disebabkan oleh beberapa faktor antara lain; metode pembelajaran yang diterapkan masih konvensional, penggunaan alat/ media peraga jarang sekali digunakan dan tidak variatif, sehingga pemahaman terhadap konsep sulit diterima oleh siswa. Selain itu, dalam pembelajaran siswa kurang dilibatkan secara aktif dan cenderung pasif, terbukti ketika pembelajaran siswa cenderung diam dan enggan bertanya meski mengalami kesulitan. Siswa kurang berusaha dan berfikir keras untuk menggali serta membangun idenya sendiri. Karena itu metode ini lebih baik jika diubah dengan metode yang melibatkan siswa secara aktif dalam proses pembelajaran yang PAKEM. Dari pembelajaran yang baik dan PAKEM tersebut, diharapkan peserta didik lebih aktif dalam mengikuti pembelajaran khususnya pembelajaran tema 4 tentang pantun. Demikian juga dengan peneliti, diharapkan peneliti maupun guru akan lebih aktif dan kreatif dalam menyampaikan pembelajaran tema 4 tentang pantun. Guru agar lebih termotivasi untuk berinovasi dalam pembelajaran yang beribas pada peningkatan kompetensi guru menjadi guru- guru yang profesional seutuhnya.

Untuk itu, penulis akan menyelesaikan masalah tersebut melalui Penelitian Tindakan Kelas (PTK) dengan alternative pada penerapan media video dalam pembelajaran untuk meningkatkan hasil belajar pada siswa kelas V SD Negeri Kedungoleng 03. 


\section{METODE}

Metode yang digunakan adalah metode penelitian tindakan kelas (PTK) yang dilaksanakan dalam tiga siklus, tahapan pada setiap siklus terdiri dari tahap perencanaan, pelaksanaan, observasi, dan refleksi. Subjek penelitian ini adalah peserta didik kelas V SD Negeri Kedungoleng 03 Paguyangan Kabupaten Brebes tahun pelajaran 2020/2021 yang berjumlah 18 peserta didik. Teknik pengumpulan data menggunakan observasi dan tes hasil belajar siswa, dan catatan hasil refleksi dan evaluasi. Analisis data meliputi analisis kuantitatif dan analisis kualitatif, penyajian data, dan penarikan kesimpulan. Hasil perbaikan pembelajaran menunjukkan bahwa penerapan media video dalam pembelajaran tema 4 tentang pantun dapat meningkatkan hasil belajar siswa di kelas V SD Negeri Kedungoleng 03 Paguyangan Kabupaten Brebes tahun pelajaran 2020/ 2021 yang dibuktikan dengan persentase ketuntasan hasil belajar pada prasiklus, siklus I sebesar $38 \%$ menjadi $77 \%$ pada siklus II.

\section{HASIL DAN PEMBAHASAN}

Berdasarkan analisis hasil penelitian yang telah diuraikan maka pembahasan pada penelitian ini sebagai berikut.

1. Penerapan Media Video

Hasil penelitian menunjukkan peningkatan penerapan media video dalam pembelajaran tema 4 tentang pantun yang dilakukan oleh guru. Terlihat pada tabel berikut.

Tabel 1. Data Penilaian Keterampilan

\begin{tabular}{|c|c|c|c|}
\hline \multirow{2}{*}{ Aspek } & \multicolumn{2}{|c|}{ Skor rata- rata } & \multirow{2}{*}{ Keterangan } \\
\hline & Siklus 1 & Siklus 2 & \\
\hline \multicolumn{4}{|l|}{$\begin{array}{l}\text { A. Isi dan } \\
\text { pengetahuan }\end{array}$} \\
\hline Memenuhi 4 kriteria & 3 siswa & 3 siswa & \\
\hline Memenuhi 3 kriteria & 10 siswa & 15 siswa & \\
\hline Memenuhi 2 kriteria & 5 siswa & 0 siswa & \\
\hline \multicolumn{4}{|l|}{$\begin{array}{l}\text { B. Penggunaan } \\
\text { Bahasa Indonesia } \\
\text { yang baik dan } \\
\text { benar }\end{array}$} \\
\hline Memenuhi 4 kriteria & 0 siswa & 2 siswa & \\
\hline Memenuhi 3 kriteria & 18 siswa & 16 siswa & \\
\hline Memenuhi 2 kriteria & 0 siswa & 0 siswa & \\
\hline C. Prosentase & $38 \%$ & $77 \%$ & \\
\hline D. Kategori & Rendah & Tinggi & \\
\hline
\end{tabular}

Pada tabel di atas dapat diamati peningkatan pemahaman siswa dalam penilaian keterampilan dalam menyusun sebuah pantun dengan beberapa aspek dalam pembelajaran dari siklus 1 dan siklus 2. Pada siklus 1 di dapat 
$38 \%$ dengan kategori rendah yang dapat disimpulkan belum menunjukkan pemahaman pada materi yang signifikan. Dari 18 siswa menunjukkan hanya 3 siswa yang memenuhi syarat- syarat penulisan pantun dengan benar, dan $62 \%$ siswa belum menunjukkan perkembangan yang bagus. Dan pada siklus 2 keterampilan siswa menunjukkan peningkatan yang signifikan dengan prosentase $77 \%$ dengan kategori tinggi.

2. Hasil Belajar siswa

Hasil penelitian menunjukkan peningkatan hasil belajar pada tema 4 tentang pantun. Terlihat pada tabel berikut.

Tabel 2 Data Hasil Belajar Siswa/ Nilai Pengetahuan

\begin{tabular}{cccc}
\hline Nilai & Siklus 1 & Siklus 2 & Keterangan \\
\hline 100 & 0 & 5 & \\
90 & 1 & 3 & \\
80 & 6 & 6 & \\
70 & 1 & 4 & \\
60 & 10 & 0 & \\
50 & 0 & 0 & \\
Tuntas & $\mathbf{8}$ & $\mathbf{1 5}$ & \\
Tidak Tuntas & $\mathbf{1 0}$ & $\mathbf{3}$ & \\
Prosentase & $\mathbf{3 8 \%}$ & $\mathbf{7 7 \%}$ & \\
\hline
\end{tabular}

Pada tabel di atas dapat di amati peningkatan yag signifikan dari hasil belajar siswa pada materi tema 4 tentang pantun. Pada siklus 1 menunjukkan angka ketuntasan siswa hanya 8 siswa yang memenuhi ketuntasan, dan sisanya tidak tuntas sebanyak 10 siswa dengan prosentase ketuntasan $38 \%$. Pada siklus 2 menunjukkan ketuntasan siswa sebanyak 5 siswa memperoleh nilai sempurna dan selebihnya merata pada nilai 90, 80, dan 70 dengan prosentase ketuntasan dicapai 15 siswa sebanyak $77 \%$.

Peningkatan hasil belajar Informatika peserta didik pada materi mengenal rumus dan fungsi Microsoft excel diukur dengan menggunakan teknik tes hasil belajar dengan instrument lembar soal evaluasi. Teknik pengumpulan data hasil belajar peserta didik diterapkan disetiap pertemuan setelah dilakukan proses pembelajaran.

Pada siklus 1 tingkat hasil perbaikan tidak menunjukkan hasil yang maksimal, baik pada ketuntasan hasil belajar maupun peningkatan pada penilaian keterampilan siswa dalam pembelajaran. Siswa yang tuntas pada siklus 1 hanya mencapai $38 \%$ dan tidak mengalami perubahan dari studi awal. Peneliti memberikan bimbingan yang intensif serta memperbanyak bahan ajar serta evaluasi guna memperdalam pemahaman siswa pada materi sehingga pada perbaikan di siklus 2 menunjukkan peningkatan yang bagus. Pada siklus 2 siswa tuntas sebanyak 15 siswa dengan kenaikan prosentase sebesar $39 \%$ dari $38 \%$ di siklus 1 mencapai $77 \%$ di siklus 2 .

Data tersebut membuktikan bahwa penerapan media video dalam pembelajaran tema 4 tentang pantun untuk meningkatkan hasil belajar siswa kelas 5 SD Negeri Kedungoleng 03 sangat tepat. Hal ini relevan dengan pernyataan Sadiman (1986) dan Miarso (1989) bahwa media pembelajaran adalah segala sesuatu yang dapat digunakan untuk menyalurkan informasi dan dapat merangsang pikiran, perasaan, perhatian, dan kemauan peserta didik sehingga dapat mendorong terjadinya proses belajar pada diri peserta didik. Hal tersebut ditunjukkan dengan peningkatan hasil belajar siswa hasilnya positif dengan rata- rata diatas KKM 68. 


\section{SIMPULAN}

Berdasarkan hasil penelitian dan uraian pembahasan maka dapat diambil simpulan sebagai berikut: (1) Penggunaan media video dapat meningkatkan hasil belajar siswa dalam tema 4 tentang pantun pada siswa kelas 5 SD Negeri Kedungoleng 03. (2) Hipotesis yang peneliti rumuskan dapat tercapai kebenarannya yaitu dengan penerapan media video dalam pembelajaran tema 4 tentang pantun pada kelas 5 SD Negeri Kedungoleng 03 dapat meningkatkan hasil belajar siswa secara signifikan.

Dari hasil penelitian diharapkan adanya penelitian lanjutan apakah media video dapat diterapkan pada pembelajaran yang lain dengan baik atau tidak. Pembelajaran dengan media video diharapkan dapat mengubah peran guru dalam penyampaian materi secara maksimal serta memberikan motivasi tersendiri pada perkembangan potensi dan kompetensi guru agar dapat tercipta media- media, alat- alat peraga yang lebih inovatif dan menarik untuk peningkatan prestasi belajar siswa di pembelajaran abad 21 yang akan kita hadapi.

\section{DAFTAR PUSTAKA}

Arikunto,Suharsimi dkk. 2006. Penelitian Tindakan Kelas. Jakarta : PT.Bumi Aksara Arikunto, Suharsimi. 2009. Dasar-Dasar Evaluasi Pendidikan. Jakarta : PT.Bumi Aksara.

Budi I, Sandi. 2019. Pendalaman Materi Pembelajaran di SD Berbasis TIK. Jakarta: Kementerian Pendidikan dan Kebudayaan.

Huda, Miftahul. 2011.Cooperative Learning : Metode, Teknik, Struktur dan Model Penerapan. Yogyakarta : Pustaka Pelajar

Kusumah, Wijaya dan Dedi Dwitagama. 2010. Mengenal Penelitian tindakan Kelas. Jakarta : PT.Indeks.

Muslich, Masnur. 2009. Melaksanakan PTK itu Mudah (Classroom Action Research).Jakarta : Bumi Aksara.

Pamungkas, Sri. 2012. Bahasa Indonesia dalam Berbagai Perspektif Dilengkapi dengan Teori, Aplikasi dan Analisis Penggunaan Bahasa Indonesia Saat Ini. Yogyakarta : Penerbit ANDI.

Rubiyanto, Rubino. 2011. Metode Penelitian Pendidikan. Surakarta : FKIP UMS. Rohmadi, Muhammad dan Yakub Nasucha. 2010. Paragraf : Pengembangan \& Implementasi. Yogyakarta : Media Perkasa.

Tarigan, Henry Guntur. 1994. Menyimak : Sebagai Suatu Keterampilan Berbahasa. Bandung : Angkasa. 